FACTA UNIVERSITATIS

Series: Philosophy, Sociology, Psychology and History Vol. 19, No 2, 2020, pp. 141 - 152

https://doi.org/10.22190/FUPSPH2002141P

Original Scientific Paper

\title{
STORIES ABOUT SOCIALIST CULTURE AS TOLD BY 'ESTRADA MUSICIANS' IN BULGARIA: TWO PERSPECTIVES ON THE PAST FROM 1990-1992 AND 2010-2018
}

UDC 316.728(497.2)

\author{
Zhana Popova \\ University of Sofia "St. Kliment Ohridski", \\ Faculty of Journalism and Mass Communication, Sofia, Bulgaria
}

\begin{abstract}
The text presents the results of a study of stories about everyday life during the last years of the socialist past (1983-1989) by representatives of a specific professional group - 'Estrada musicians'. The main goal is to highlight the differences in the two regimes of history in the memories of the socialist popular culture. The first regime of remembrance (1990-1992) is a time of the emotionally charged anti-communist speech in the media like the Democracy newspaper, and vice versa - a strong defense of socialist values in the Duma newspaper. The second regime of remembrance is after 2010, when "nostalgia for socialism" stands out as one of the dominant emotions.
\end{abstract}

Key words: estrada musicians, socialism, everyday life, media culture.

\section{INTRODUCTION}

Estrada music is not only a Bulgarian phenomenon of mass culture, but has a particularly important role in Bulgarian media culture. Created in a Soviet model in the late 1950s, estrada art was characteristic as an idea of working people's entertainment in almost all former socialist countries. Since the late 1960s, there has been a dual reception of estrada music: contact with the audience during concert tours in the country and abroad, and a second audience - through the recordings of estrada music on the radio, and then on the television through a consistent state policy to validate estrada music as the main form of entertainment music on the state radio (Angelova 2018, 2020, Petrova 2019) and then Bulgarian TV (see Dimov 2019 and Statelova 2019).

Received June 27, 2020 / Accepted July 20, 2020

Corresponding author: Zhana Popova

University of Sofia "St. Kliment Ohridski", Faculty of Journalism and Mass Communication, Moscovska St 49, 1504 Sofia, Bulgaria

E-mail: ztpopova@uni-sofia.bg 
After 1990 in Bulgaria estrada music not only did not die out, but played an important role in the programs of new private radio stations and television channels.

The main thesis of the study is that the stories in the media and in autobiographical books with memories of the everyday practices of people who provided entertainment during state socialism are part of the communicative memory of certain stages of a historical age before it was transformed into an element of the cultural memory of an absolute past (Assmann 2001).

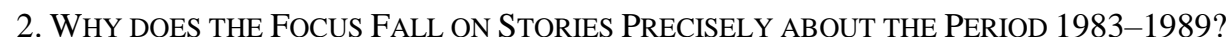

The period 1982-1989 (and especially after 1985) saw significant changes in the trade and cultural exchange between the Bulgarian state and part of the socialist camp countries.

According to some historians studying the socialist past, in the autumn of 1984, Bulgaria undertook a policy of convergence between the country and the Federal Republic of Germany, "which cast the first shadow on the personal relations between Zhivkov and Gorbachev" (Baeva and Kalinova 2006, 225). As early as the mid-1980s, when Mikhail Gorbachev came to power, the Bulgarian-Soviet relations changed. With his second visit to our country, Gorbachev had "a second goal, i.e. to prevent T. Zhivkov's visit to Bonn, which was perceived by Moscow (by K. Chernenko's team) as going beyond traditional coordination of actions, as it contradicted the strained relations between the USSR and the Federal Republic of Germany" (Baeva and Kalinova 2006, 224-225). According to Baeva and Kalinova, Gorbachev's mission was unsuccessful. At the end of the era, in 1987-1988, when Gorbachev's perestroika entered its radical phase - the "Glasnost Era" (Baeva and Kalinova 2006, 231), Bulgaria continued to maintain excellent political and economic relations with the Federal Republic of Germany.

Vyara Angelova showed that in the 1970s, the radio promoted Bulgarian popular music to serve as an exchange in the entertainment of the socialist camp (Angelova, Bulgarian Radio during Socialism (D.Sc. Thesis) 2020, 100-101). According to Ivan Elenkov, a researcher of socialist mass culture, in the 1980s, the state began to develop the idea of 'economization of culture' (Elenkov 2012, 516). Petya Kabakchieva analyses the paradox of 'the state sponsorship of the market' according to a group of Bulgarian artists after 1986 (Kabakchieva 2016, 284-315).

This gives reason to consider the stories told by musicians after 2010 - about their work abroad - as a trial version of the idea of economization of culture included in official documents.

The research interest in musicians' memories of this precise period is related to the dual status of musicians in the 1980s. A significant number of Bulgarian estrada musicians negotiated their seasonal jobs in bars, cruises and popular restaurants in GDR, Scandinavia, as popular music performers. During this period in Bulgaria, many of them worked for fees and were not appointed on the state payroll as performers of Bulgarian pop music, and abroad they were employed workers because of their skills, playing and singing cover versions of popular songs.

This study regards estrada musicians as 'active people' similar to the people described by Jean Rancière: "(...) those living in the time of possible events, the time of action, and its purposes, that is, the time of knowledge and leisure." Rancière says that the other category includes passive or mechanical people; "they live in the world of ordinary means, without 
being involved in either the purposes of action, or the self-purpose of leisure activities" (Rancière 2018/2,128). The main difference is that musicians describe their conditions: during the regime of the Bulgarian Communist Party they are active but not free persons.

After 1983, Bulgarian estrada musicians lost part of their jobs in the country, as concert tours decreased. The institution that regulated estrada musicians' work was the Bulgarian Concert Directorate, and tours abroad and contracts with foreign employers were arranged through a state artist management bureau. Estrada musicians had quotas of how many concerts they should perform in the country, the biggest celebrities of the Bulgarian estrada had pre-approved tours in the USSR and the countries of the socialist camp, and when they fulfilled this work cycle quota, musicians were given the opportunity to negotiate work in entertainment establishments abroad. The analysis focuses on the stories of recent years of the country's socialist development, as the authors' assessments of socialism are related to the hierarchy of places from which they tell the stories - memories from "home" and memories from "abroad". According to Kolyo Koev: "In spite of my various spatial localizations, according to which I should as though always encounter different things, I identify these things (the above-mentioned practical formalization) from a certain viewpoint every time when I am changing my "position", I retain the perspective (das Gegenüber), from which I behold things" (Koev 2010).

In Bulgaria, estrada performers were socialist celebrities in the space of active people who worked for the leisure-time entertainment of others. In bars abroad (German Democratic Republic, Scandinavia), they occupied a space which is similar to "the space of craftsmen" (Rancière 2018/2, 127).

Through special fee rates, the state secured the payment of copyright for the broadcasting of their performances on radio and television. So while the singers were abroad, their songs were part of the Bulgarian listeners and viewers' everyday lives. It is also interesting to track how through these stories in the media and in their memoirs, musicians of the recent past try to "close the old biography" (Popova 2001, 82).

This analysis understands everyday life as a shared world in which people live together and which is obvious (Schütz and Luckmann 1979, Habermas 1988), and the analysis of different meanings of retrospective descriptions of the social order by Kolyo Koev (Koev 2010, 292).

To highlight what the work and entertainment in estrada musicians' everyday lives looked like at the end of state socialism, two periods of time, removed from the period of interest, were chosen as viewpoints from which to analyze it.

The first period, 1990-1992, was immediately after November 10 1989, when the Politburo of the Bulgarian Communist Party announced the resignation of Todor Zhivkov (party leader since 1954). This is a period of transition to democracy when a multi-party system was created in the country and a press developed - with party editions, tabloids and the yellow press. Media stories with memories of estrada musicians about socialism from the pages of two party newspapers Duma and Democracy were analyzed. The second period is a period of remote view of the experience at the end of the Bulgarian Communist Party's rule-memories in autobiographical books published in the period 2010-2017.

In print and in books, memories are dated. The moment of telling the memories is related to certain historical events, crises and conflicts. This type of dated narrative is also analyzed vis-a-vis the context of the storytelling time, which is noted by the author.

The second period 2010-2017: printed memories compete with the oral memory of estrada music, especially after the development of online platforms, and daily sharing of 
music from the past on YouTube. According to a concept developed by Jose van Dijck, this sharing leads to a merger of personal and collective memories, with internet users being "individual agents" of memories and collectors of media representations of the past (Dijck 2006, 358). Audio-video recordings broadcast by traditional televisions appeared on the internet, shared because of certain emotions. Therefore, Ivaylo Ditchev points out the victory of the image over the audio (Ditchev 2016, 83).

The differences in the two regimes of history in the memories of the socialist past are: the first regime of remembrance is the time of the emotionally charged anti-communist speaking in some media like the Democracy newspaper, and vice versa - a strong defense of socialist values in the Duma newspaper. The second regime of remembrance is post-2010, when "nostalgia for socialism" stands out as one of the dominant emotions (Mihelj 2017; Koleva 2011).

\section{STUDY FRAMEWORK}

The total number of interviews with estrada musicians in the Duma and Democracy newspaper is 264, with a precedence of 80 units for the Democracy newspaper. Party newspapers created in 1990 were selected: the Bulgarian Socialist Party's Duma newspaper (which replaced the Bulgarian Communist Party's Rabotnichesko Delo), and the Union of Democratic Forces' Democracy newspaper.

The analyzed autobiographies include: 'Istinata. Lili Ivanova' by Lili Ivanova 2012; 'Zabravih si chasovnika na pianoto' by Mitko Sterev, 2010; 'Au-u, ot glad umiram' by Razvigor Popov, 2010; 'Bogdana na 20, i na 30x2' by Bogdana Karadocheva, 2010; 'Mazhat na 60. Intimno' by Stephan Dimitrov, 2011; and 'Blagodarstvena pesen' by Bisser Kirov, 2017.

\section{1980S AND SOCIALIST ENTERTAINMENT}

This text focuses on memory-based reconstruction of the way musicians themselves talk about socialist entertainment culture over the last decade of socialist development, i.e. in the period 1983-1989.

In addition to the propaganda and ideological role, this part of popular culture was transformed into a prototype of a socialist cultural 'economic form' from which the state could benefit and use it to finance other areas of the cultural sector.

The first result is related to the naming of the time. The era before November 1989 was named by musicians 'socialism' and 'communism'. The present in which they live post-1990 - is described as 'transition', 'democracy', 'wild capitalism'.

In the two newspapers (despite their different party identifications), musicians refer to radio and TV broadcasting of 'good songs' being suspended by a committee imposing numerous bans, as the reason for the end of estrada music.

Their autobiographies after 2010 paint a different picture. Musicians refer to the same reason for the collapse of estrada entertainment after 1983: according to them, Bulgaria followed the world trends. Disco music had conquered Western Europe, and discos with DJs and recording equipment appeared in the mid-1980s in Eastern Europe. This put an end to concert tours in the country. 
According to the composer Mitko Shterev, estrada music died in the mid-1980s in Bulgaria. According to him, in 1984, "dance music in Bulgaria reached its peak" (Sterev 2010, 42). "This coincided with the appearance of Michael Jackson and his music. Although I had two hits, the audience at our concerts began to decrease progressively until it came to the point that our second concerts (we almost always did two) sold a little more than half of the seats. (Sterev 2010, 42).

According to composer and artist Razvigor Popov "In the 1980s, the copies of all phonograph records gradually began to decline. It turned out to be a worldwide phenomenon. Technology was going forward, and tapes replaced phonograph records. On tape, however, anyone could record music on their own, according to their taste in the so-called "pirate" way. If this was done for personal use, there was nothing wrong with it. But if it became an industry, we, the authors, sustained losses" (Popov 2010, 322).

While the memories of the committees that imposed bans did not disappear in the books after 2010, the main problem for musicians was the inability to perform as composers. "First a committee in the radio was given the text. Then a second committee would listen to the songs written as notes for the piano and vocals and decide which to accept and which to reject. The committee was appointed by the Union of Composers and only tolerated its members" (Krasimir Levashki of Diana Express band, Sterev 2010, 86).

\section{ESTRADA Music IS 'DECADENT’, ESTRADA Music IS 'EuROPEAN’}

During the first period from 1990 to 1992, musicians gave press interviews as participants in social and political changes. Some of them became politicians, joined the National Assembly, others actively participated in election headquarters and were responsible for campaigning. Others disappeared from the public eye. On the street, some of the former estrada musicians took part in the political rallies of the two largest parties in the first years of the transition to democracy - the Bulgarian Socialist Party (BSP) and the Union of Democratic Forces (UDF).

This was the time for songs loaded with democratic pathos. As early as 1991, 'anthems of democracy" were recorded on tape that contained slogans like "Communism is gone!" (Poduene Blues Band, 1991), "I am not a communist and I never will be./I am not a nihilist and I never will be./I am not Antichrist and I never will be./I'm just a man" (Shturtsite, 1991), "Give me a divorce" (Asen Gargov, 1991) with the lyrics "Take the panels and the Trabant but spare me the air!"; "Tomorrow starts today" (Diana Express, 1991), "The time is ours" (Bogdana Karadocheva, Vasil Naydenov, Rositsa Kirilova, Vili Kavaldzhiv); "Lift your gaze" (Valdi Totev, 1991). Musicians praised the separation from communism and distrust to the new socialist party. In the "Last Waltz" (again a group of musicians, 1991) they sang: "You promised well-being and you were young, shy / I believed this lie / you were so pretty with it... / Last waltz ... Goodbye, my love... / I'll remember you even with the new name ${ }^{1} \ldots$

During this period, the "traumatic narrative of socialism" (Koleva, Socialism as a Biographical Project: Narrative Resources and Strategies 2017, Vukov 2017, Kiossev 2017) was particularly strong and it found its place on the pages of the newly created Democracy newspaper. The theoretical framework follows the concept by Liliana Deyanova

${ }^{1}$ The song's message is related to the change of the name of the Bulgarian Communist Party to Bulgarian Socialist Party. 
about memory, remembering and forgetting (Deyanova 2008). In the media Duma newspaper and Democracy newspaper, this was also the time when the key to the development of the new biography was sought (Popova 2001).

In the 1990s, estrada musicians were still perceived as the popular faces of music created during socialism. Their post-1990 ideological choices expressed in the media are notable, as they are the "former socialist celebrities" who chose the path of the "new democratic man" or supported the "new left". UDF, however, lost the first democratic elections. The Duma newspaper of the victorious party, BSP, criticized "former estrada celebrities" for having used all the benefits of socialism, while after 1989 they chose to be on a "feeding rack" under the UDF's future power.

Both newspapers showed a rapprochement of the memories that estrada music performed during socialism was viewed by those in power as "degraded music", as a "light genre". Vyara Angelova's study of the party leadership's understanding of the entertaining music on the radio until 1989 shows that this was just one way, among others, to define it (Angelova, Bulgarian Radio during Socialism (D.Sc. Thesis) 2020). Angelova shows that radio music editor's offices and the party leadership did not underestimate the impact of estrada music, but tried to use the power of its influence.

In the autobiographies of estrada musicians after 2010, we find the same dominant self-description. Lili Ivanova, referred to in the media as "the Grand Dame of Bulgarian Estrada", writes: "Estrada was not elite, it was decadent. As is now - estrada has always been considered the periphery of Bulgarian culture in general. Unlike in all other countries." (Ivanova 2012, 185).

After 2010, some musicians avoided using the definition of "estrada music" and replaced it with "pop music". According to the composer and arranger Mitko Shterev: “(...) at almost all levels, pop and rock music was considered decadent. For category two music. This forced bands such as Tangra and Signal to debut with songs written by pop composers, members of the Union of Bulgarian Composers: "The Landlady's Song" and "Maybe" (Sterev 2010, 86).

This is a specific aspect in the memories of estrada musicians' daily work - they were not part of the professional artistic unions and their repertoire was determined by various committees on aesthetic and artistic quality at the Balkanton recording institution, on the radio and television (Dimov 2019; Statelova 2019).

The memories after 2010 included in musicians' autobiographical stories feature a slightly different picture from the one described by musicians in the period 1990-1992 in the media: Bulgarian estrada music is at the level of European pop music. Almost all the musicians express gratitude to the most popular singer Emil Dimitrov for teaching them to view estrada music as European music. Emil Dimitrov himself "dressed like a Frenchman", Mitko Shterev says about him. "Therefore, he was hated by the Union of Composers who did not allow his songs on Radio Sofia" (Sterev 2010, 28). Bogdana Karadocheva and Stefan Dimitrov, Biser Kirov, Lili Ivanova tell the same memories of him.

By the 1980s, "a new culture had been already built", with massive amounts of production and distribution, charged with expectations to be ideologically (pre)educational toward new cultural habits. It is possible to regard the "Universal Complex Program for Aesthetic Education of Workers and Youth" created in 1975 as the end point of its conceptualization (Elenkov 2012, 514).

From 1967 to 1974, the socialist state invested funds for the development of the largest International music festival 'Golden Orpheus, which promoted the country. The festival venue 
was the Sunny Beach resort and the festival served as an advertisement of tourism along the Bulgarian Black Sea coast. Bisser Kirov writes: "By the mid-1980s, "Golden Orpheus" was one of the most prestigious pop festivals in Europe. (...) with over 300 million viewers. This was a gigantic propaganda of "socialism with a human face" and naturally of the growing Bulgarian tourism industry" (Kirov 2017, 155). The recordings from the Golden Orpheus festival became part of the national radio and television archive.

\section{Two PERSPECTIVES ON EVERYDAY LIFE OF MUSICIANS}

In their autobiographical narratives post-2010, musicians highlight an important value to them - working and having fun together, a special value: togetherness.

Printed editions include the respect of all musicians who did not declare their political choices after the change. They disappeared as popular faces, as significant modes of forgetting. In interviews in the 1990-1992 press, it is difficult to find strong political messages, they are rather a background of politicians from a new opposition force. Lili Ivanova uttered the slogan "Culture over politics!" (Democracy, 24. 04. 1991), the musicians from Shturtsite, and Stefan Dimitrov spoke about the repression by the ruling party, which consisted of breaking guitars, cutting long hair or suspending their concerts. The main motifs in the stories of former estrada musicians on the time prior to 1989, which were published in the opposition Democracy newspaper in 1990-1992, include: "communism limits our freedom", "communism is a deficit of goods and Western culture". In Duma newspaper of the newly named Bulgarian Socialist Party, mostly through journalists' questions, musicians were urged to talk about the "totalitarian machine", the "totalitarian system" of the communist regime to be substituted by free and democratic socialist rule. Newspapers tended to mix communism and socialism as ideologies. Totalitarian repression against jazz performers such as Lea Ivanova and Asen Ovcharov were condemned in both newspapers. The opposition Democracy newspaper voiced the request that "the state should take care of Bulgarian rock", which was damaged against the backdrop of estrada prior to 1989. This is one of the paradoxes of political talk about music in the period 1990-1992, because the left-wing Duma newspaper insisted on a market principle and having the audience decide which music should continue to live, and on the pages of the rightist newspaper, Lily Ivanova, Stefan Dimitrov, Vasil Naydenov, and new rock musicians insisted that the state take care of Bulgarian music after 1990.

In their autobiographical books post-2010, musicians shared much more about their past, presenting themselves as the strong generation in Bulgarian music, talking about themselves as part of a musical community.

After 2010, why do musicians mostly remember the country's negligent attitude toward the estrada? One of the possible answers is: because they personify the socialist regime of government. In their autobiographies after 2010, the state that organized concerts, tours in the countries of the socialist camp, and oversaw side jobs of bands abroad is represented by the positive image of the head of the Bulgarian Concert Directorate. Similarly, censorship is personified. They explain their songs being taking off the state radio as the choice of the editors on the radio, who had personal reasons not to like them.

Despite these bans, musicians talk about their life together with other musicians, celebrating together at the seaside, tours with colleagues from other bands. This togetherness, as a daily value, is told by Razvigor Popov: "Money was a good thing, but not the most 
important thing. What was important was what we all did on stage, together. We could see the smiling faces of the crowd, their misty eyes, and that magic on the stage that made us happy" (Popov 2010, 46).

The nostalgic discourse on the 1983-1989 period is strongest in two completely opposite books, just like the political bias of their authors - those by Bogdana Karadocheva, who was one of the faces of UDF, and of Biser Kirov, who worked in campaigns of politicians from the left. Of all the authors of autobiographies, Bogdana Karadocheva uses the term "communism" most often to refer to the era until 1989. She brings back memories of "bad communism" when some books were hard to find, but "(...) God, we read so much! We had friends at bookstores all over Bulgaria who would help us get access to all the newly published books. We knew a lot about books, music and fashion. We didn't want to fall behind the big world" (Karadocheva 2010, 54). Her memory of the entertainment at home is: "We would get together in our homes at night, listen to forbidden music and dream. (...) We would get together (...) to watch Serbian television. It was a big deal! Even though there were "snowflakes" on the screen (Karadocheva 2010, 55). The comparison with "today's generation" goes through the description of music choices: "Then we didn't drink so much. Well, one whiskey, one or two glasses of wine - I think we were more Europeans than we are now. Brandies, chalga, belly dances and vulgarities were a trademark of Gypsy weddings" (Karadocheva 2010, 55).

In the memories of Bogdana Karadocheva, who retained her position as an anticommunist, the traumatic account of the death of her father Ivan Karadochev, who was sent to one of the "labour camps" during the previous regime in Bulgaria, is combined with a nostalgic narrative of the time of intellectual get-togethers and a lot of work. Karadocheva summarizes communism as an ideology that she cannot accept because of people's distancing from believing in God. At the same time, however, the autobiographical narrative shows us the enjoyment of meetings organized precisely by the party power with various artists from around the world - Vladimir Vysotsky, William Saroyan (Karadocheva 2010, 40).

The everyday life of musicians was filled with travel, recording albums and continuous exchange of cultural influences: "I made an album with very nice arrangements by Nayden Andreev and recorded songs like Michel Legrand's "Windmills", songs by Shirley Bassey, and Bulgarian songs. The lyrics were mainly written by Zahari Petrov, a very colorful personality with great knowledge and an even greater collection of jazz and pop music. Everyone who traveled abroad would bring him records" (Karadocheva 2010, 41).

Another composer, Stefan Dimitrov, speaks of his return from Malta, where he represented Bulgaria, together with the singer (and later his wife) Bogdana Karadocheva: "We came back and we threw ourselves into our work. We wrote songs and lyrics. (...) Eighty concerts a year" (Dimitrov 2011, 51).

The main point in time used for comparison by musicians is that post 1990: "It seems to me I live in a society full of degenerates with a changed value system. Their role models are characters from Turkish television series, participants in various reality shows, goons and chalga singers. Against this background, the music I have composed seems false and worthless" (Dimitrov 2011, 98-99).

This generational comparison in the stories is not continued with an explanation as to how the mafia, chalga, and low culture took the place of estrada music. In estrada celebrities' autobiographies, there is no self-reflection on where "the next generation", which is "cynical, rude, and devoid of culture other than chalga" came from. This leads to the naming of the post-1989 period "democracy": "I have heard the reproach that 
communism created me. It didn't make me, I was born and I lived in the time of communism. It couldn't have made me. Now we have total freedom and democracy. Let them create or help self-create others" (Ivanova 2012).

\section{BETWEEN OSTANKINO AND HUMPHREY BOGART: BETWEEN STAR TOURS IN THE USSR AND HARD WORK “ABROAD”}

Eight-hour piano playing, daily duties - this is what the day of musician working abroad looked like in the last decade before the fall of the Berlin Wall (Dimitrov 2011; Popov 2010). Biser Kirov adds that the work of Bulgarian singers was valuable because they were cheap labor (Kirov 2017).

In the late 1980s, the number of tours in the USSR dropped. All authors talk about the Soviet audience, which applauded Bulgarian musicians. They admit that Lili Ivanova and Emil Dimitrov were accepted as celebrities by the Soviet audience. Stefan Dimitrov, who was one of the faces of the "blue idea" of the Union of Democratic Forces after the collapse of the regime of 1989, admitted that Bulgarian musicians were respected in the USSR, but the repressive regime of the government there repelled him. However, he is proud in his memoirs that "Years after the tour with Lili, they played one of my songs in Ostankino ${ }^{2}$. Something like Eurovision, but it was called Intervision, for socialist countries" (Dimitrov 2011, 46). The Intervision contest is part of the places that consolidate the group, one of the symbols of its identity and support points of its memories. As Assman writes: "Memory needs spaces." (Assmann 2001, 37).

Biser Kirov explains his success in Cuba, Hungary, Romania, USSR, and especially in the GDR, where he sang until November 10 1989, with his undisputed qualities as an artist. Lili Ivanova explains her departure to GDR in the 1980s as a chance occurrence: "Somebody will probably think I've pulled some strings to go to Germany again. Actually, fate is the most illogical and funny thing. One sunny day, I met a German man with his wife on the street, and they asked me (...) I was with Ivan Tenev. He speaks German. It turned out that this was Volker Naumann, one of the directors of Friedrichstadt-Palast, Berlin" (Ivanova 2012, 189).

Stefan Dimitrov says: "We left for Scandinavia - Oslo, Stockholm, Helsinki. We also went to Lapland, behind the Arctic Circle. We also played on huge North Sea ferries. Hard work without a break. We didn't disembark for forty days" (Dimitrov 2011, 51).

Many described their difficult attempts to remain working, post-1990, "in the West" but wanted to return to create music. "We would leave, but we would always come back. Years later, Nora Nova got us a gig at a piano bar in downtown Munich. Near the opera house. That was great! We bought white jackets at a store where they sold clothes from Hollywood productions. Mine might have been worn by Humphrey Bogart (in "Casablanca" he wears the same). I played for so long, from eight to half past two every night, my back hurt. It's a very specific job in a piano bar. You have to entertain everyone. This happened in Gstadt, in Thessaloniki, on the island of Sylt and everywhere" (Dimitrov 2011, 53).

After 2010, in their biographies, musicians describe how they used their tours abroad, especially to the GDR, to obtain stage costumes, equipment, or stage effects for their

\footnotetext{
${ }^{2}$ Ostankino Tower (Moscow) for radio and television broadcasting is used here as an image of the Intervision contest broadcast through which some socialist countries got together to respond to the EBU's Eurovision TV song contest.
} 
concerts in Bulgaria. They highlight the differences in the way musicians' work was perceived in the socialist camp, where they worked as popular persons, and abroad, where they were employed on fixed-term contracts. Abroad, they were paid several times more. About the GDR, Lili Ivanova reports the well-arranged trade union activity in the music industry. After the fall of the Berlin Wall, Germany chose to protect the jobs of local musicians rather than foreign hires, no matter how good the latter were. Authors describe their well-paid jobs in Scandinavia, but long-hour and prolonged work.

What kind of music did they play abroad? Lili Ivanova says that she bought the lyrics and scores of songs in German from a bookstore and studied them to present them to her audience. Bogdana Karadocheva sung Russian romances in one of the famous bars in Paris.

Composer Stefan Dimitrov talks about one of the contests he was invited to as a jury member. "We gave a prize to their Stefan Dimitrov. There was an English composer on the jury. He had had the chance to write a song that Tom Jones liked and sang. And he'd been living on the copyrights since then. He asked me if we knew the song behind the Iron Curtain. We knew it. So what - "Delilah" (Dimitrov 2011, 50).

Musicians barely comment on "the perestroika", although it was the most important event in the period they were talking about. The policy led by Mikhail Gorbachev resulted in a reduction of tours in the USSR and musicians were deprived of a secure income. None of them, however, say they expected the fall of Todor Zhivkov's rule on November 10 1989. With the exception of Biser Kirov, who was in Berlin and witnessed the collapse of the Berlin Wall, all the others say that they saw "communism going away" on television.

\section{CONCLUSION}

The period between 1983 and 1989 was particularly interesting because of the combination of internal and external processes that ended with the internal changes of the regime on November 10, 1989. After 1981, the end of the "Lyudmila Zhivkova epoch" in the country's cultural policy was marked. Zhivkova was the daughter of the Bulgarian Head of State Todor Zhivkov and she implemented a large-scale cultural program to promote Bulgarian culture. After her sudden death, however, the Communist Party entered a phase of "historization of culture", followed by a phase of "encominization of culture" (Elenkov 2012). The external process was related to the announcement of the "perestroika of socialist government" initiated by Mikhail Gorbachev. The opposition of Bulgaria's foreign policy and the USSR led to a drop in Bulgarian musicians' gigs in Soviet concert halls.

The combination of these two processes led to a change in the everyday life of authors and performers of estrada music in Bulgaria. The last years of socialist development were a period of declining concert activity in the country for Bulgarian estrada musicians. Discotheques appeared, following the model of the Western entertainment industry, albeit organized in the youth centers of Dimitrov's Communist Youth Union in Bulgaria. In the 1980s, the so-called "informal culture" and the protest of young people emerged through the choice of music, as an alternative to the music officially broadcast on the radio and TV (Samardzhieva 2018/4). The analysis of musicians' stories about the last years of socialism from two different perspectives, the close view on 1990-1992 and the more distant on 2010-2017, shows several revaluations. In the 1990s, the anti-communist messages were the dominant refrain, which included stories of musicians in the media, highlighting the bans on broadcasting and recording songs by Balkanton and Bulgarian radio and 
television. Since 2010, the process of extinction of estrada music has been redefined in the autobiographical books of musicians in the picture of world trends: the boom of discos and DJs, as well as the accelerated development of recording technology. The autobiographies of the most prominent anti-communists, such as Bogdana Karadocheva and Stefan Dimitrov, flowed into the stream of "nostalgia for socialism", as they referred to themselves as part of the cultural elite. However, the stories of the last decade show that power developed a direction in socialist mass culture: the state organized the export of musicians through contracts with impresario offices, especially for restaurants in GDR and Scandinavia. The stories after 2010 mix memories of everyday party life and the sharing of cultural values in the musicians' community during the tours across Bulgaria with the memories of arranged accommodation, yet difficult work as foreign musicians in bars and restaurants. Some of them returned for the second time in a few years. 30 years later, musicians continued to sing and talk about estrada music that had been created during the time of state socialism. Estrada music continues to be broadcast on the Bulgarian radio and TV and is superimposed in communicative memory, although the death of the socialist estrada is continually proclaimed.

Acknowledgement: The paper is a part of the research done within the project 'The Soft Power of Popular Music in the Media (Examples from Bulgaria and the Balkans)', funded by the Bulgarian National Science Fund.

\section{REFERENCES}

Angelova, Vyara. Bulgarian Radio during Socialism (D.Sc. Thesis). Sofia: University of Sofia, 2020. Angelova, Vyara. "Bulgarian Radio during Socialism. Professional Media Outlets (1944-1989)". Medialog 4 (2018): 137-171.

Assmann, Jan. Cultural Memory. Sofia: Planeta-3 Pbl, 2001

Baeva, Iskra and Evgeniya Kalinova. The Bulgarian Transitions 1939-2005. Sofia: Paradigma, 2006.

Deyanova, Liliana. The Outlines of Silence. Sofia: Critique and Humanism Pbl., 2008.

Dijck, Jose van. "Record and Hold: Popular Music between Personal and Collective Memory". Critical Studies in Media Communication 23, 5 (2006): 357-374.

Dimitrov, Stefan. Мъжът на 60. Интимно [BG title: Mazhat na 60. Intimno]. Sofia: Trud, 2011.

Dimov, Ventseslav. Music for the People on the Media Front (The Soft Power of Bulgarian Folk and Popular Music under Socialism). Sofia: Sofia University Press, 2019.

Ditchev, Ivaylo. "Pop-socialism - pop-transition". In Culture as Distance: Eleven Essays in Cultural Anthropology, 63-83. Sofia: Sofia University Press, 2016.

Elenkov, Ivan. The Cultural Front. Sofia: Institute for Studies of the Recent Past, 2012

Habermas, Jürgen. Theorie des kommunikativen Handels. Zweiter Band. Frankfurt a. M.: Suhrkamp, 1988.

Ivanova, Lili. Истината. Лили Иванова [The Truth. Lili Ivanova]. Sofia: Ciela, 2012.

Kabakchieva, Petya. Communist Modernities. The Bulgarian Case. Sofia: Sofia University Press, 2016.

Karadocheva, Bogdana. Богдана на 20, и на 30x2 [BG title: Bogdana is 20 and 30x2]. Sofia: Zhanet-45, 2010.

Kiossev, Alexander. "Living in Non-Freedom: Five Parallel Lives". In The Difficult Narrative, edited by Alexander Kiossev and Daniela Koleva, 243-278. Sofia: Institute for Studies of the Recent Past, 2017.

Kirov, Biser. Благодарствена песен [ВG title: Blagodenstvena pesen]. Sofia, 2017.

Koev, Kolyo. "Description and Uncertainty: On the Sociological Relevance of Heidegger's Formal Indication". Sociological Problems 280-292. Sofia, 2010.

Koleva, Daniela. "Hope for the Past? Postsocialist Nostalgia 20 Years Later." In 20 Years After the Collapse of Communism: Expectations, Achievements and disillusions of 1989. Peter Lang, 2011.

Koleva, Daniela. "Socialism as a Biographical Project: Narrative Resources and Strategies". In The Difficult Narrative, edited by Daniela Koleva and Alexander Kiossev, 59-80. Sofia: Institute for Studies of the Recent Past, 2017. 
Mihelj, Sabina. "Memory, Post-socialism and the Media: Nostalgia and Beyond". European Journal of Cultural Studies 20, 3 (2017): 1-16.

Petrova, Angelina. "Ideology and Impossible Transformation into Mass". Medialog 5 (2019): 93-113.

Popov, Razvigor. Ay-y, от глад умирам! [Bg title: Au-u, ot glad umiram]. Sofia: Propeler, 2010.

Popova, Snezhana. Social Time and Media Narrative”, 1989-2000. Sofia: LIK. 2001.

Rancière, Jacques. "Temps, récit, politique" [Време, разказ, политика. trans. Svetlana Dimitrova]. Critique and Humanism, 2018/2.

Samardzhieva, Mihaela. "Reactions of Bulgarian Youths to three 'extraordinary' Events for the 1980s Archives". Medialog 4 (2018): 114-130. Sofia.

Schütz, Alfred and Tomas Luckmann. Strukturen der Lebenswelt. Frankfurt A.M.: Suhrkamp, 1979.

Statelova, Rozmari. Estrada and Socialism: Glimpses. Sofia: Riva, 2019.

Sterev, Mitko. Забравих си часовника на пианото. [BG title: I forgot my watch on the piano]. Sofia: Pres, 2010.

Vukov, Nikolai. "Remembrance Testimonies in Journalistic Context: (Auto)biographic Narratives, Memoirs and Letters in the Bulgarian Press of the 1990s". In The difficult narrative, edited by Alexander Kiossev and Daniela Koleva, 149-166. Sofia: Institute for Studies of the Recent Past, 2017.

\section{PRIČE O SOCIJALISTIČKOJ KULTURI KOJE SU ISPRIČALI ESTRADNI MUZIČARI U BUGARSKOJ: DVA POGLEDA NA PROŠLOST OD 1990-1992 I 2010-2018.}

Tekst predstavlja rezultate analiza priča o svakodnevnom životu tokom poslednjih godina socijalističke prošlosti (1983-1989) koje su ispričali predstavnici jedne profesionalne grupe - muzičari sa estrade. Glavni cilj je da se istaknu razlike koje postoje između dva režime u sećanju socijalističke popularne kulture. Prvi režim (1990-1992) je vreme emotivnog naboja antikomunističkog govora u medijima, u tekstovima novina Demokratija i obratno - snažna odbrana socijalističkih vrednosti u novinama Duma. Drugi režim je onaj nakon 2010, kada se 'nostalgija za socijalizmom' ističe kao jedna od dominantnih emocija.

Ključne reči: estradni muzičari, socijalizam, svakodnevni život, medijska kultura. 